\title{
Mixed hepatoblastoma in the adult: case report and review of the literature
}

\author{
RP HONAN AND MT HAQQANI \\ From the Department of Pathology, Walton Hospital, Rice Lane, Liverpool L9 1AE, UK
}

SUMMARY A case of mixed hepatoblastoma in a woman is described. A survey of the English literature reveals 13 cases acceptable as mixed hepatoblastoma; these have been described and published under a variety of names. Difficulties in nomenclature and the histology of these cases are discussed. Diagnosis depends on the identification of both malignant mesenchymal and malignant epithelial elements. The former include myxoid connective tissue resembling primitive mesenchyme and areas resembling adult fibrosarcoma. Mature fibrous tissue with calcification and bone formation may be seen. Epithelial areas show tissue resembling fetal liver, poorly differentiated epithelial cells, and/or areas of adenocarcinoma. The current view on histogenesis is also given.

Most hepatoblastomas occur in children under the age of 2 years. ${ }^{1}$ Hepatoblastoma in adults is extremely rare, and the prognosis is much worse than in the mixed hepatoblastoma of childhood.

The literature of mixed hepatoblastoma in adults has until recently been confused, and the true incidence of the tumour obscured, owing to the various names used by different authors to describe their cases. The commonest pseudonym is 'mixed malignant tumour', ${ }^{2-4}$ an ambivalent term which merely denotes the presence in one tumour of tissues derived from more than one germ layer. Study of the histology in these cases shows that many of them fulfill the criteria for a diagnosis of mixed hepatoblastoma. Sometimes, indeed, the authors admit that only an origin from embryonic cells can satisfactorily explain their histogenesis. Presumably there is a reluctance to use the suffix 'blastoma' in cases occurring in elderly patients, although there are no essential histological differences between these tumours and hepatoblastoma of infancy. It should, however, be stated that not all cases described as 'mixed tumour' represent hepatoblastoma. This is made clear when surveying Milman's cases, ${ }^{5}$ collected from a review of the earlier literature. True hepatic teratoma, for example, may occur. Other names under which mixed hepatoblastoma of the adult has masqueraded include hepatic embryonic

Received for publication 25 March 1980 mixed tumour, ${ }^{6}$ carcino-osteochondromyxosarcoma, ${ }^{5}$ and rhabdomyosarcohepatoma. ${ }^{7}$

\section{Case report}

\section{CLINICAL PRESENTATION}

A Chinese woman aged 27 had been resident in England for eight years. She gave a history of 18 months' intermittent right-sided chest pain and upper abdominal discomfort. She had previously been well. There was pyrexia, a right-sided pleural effusion, and a smooth, tender, markedly enlarged liver. Laboratory findings included: $\mathrm{Hb} 11$ $\mathrm{g} / \mathrm{dl}$ (microcytic, hypochromic blood film), white cell count $12.5 \times 10^{9} / 1$ (neutrophil polymorphs $90 \%$ ). Biochemistry, including liver function tests, was essentially normal. Blood cultures and screening for tuberculosis were negative.

A diagnosis of hepatic amoebic abscess was thought most likely. Metronidazole was started. Faecal parasites were repeatedly negative, but serology showed a weakly positive fluorescent antibody test for Entamoeba histolytica (titre 1/16). An abdominal $x$-ray confirmed hepatomegaly, and an opacity overlying the right kidney was noted. Two years previously an abdominal $x$-ray had shown a raised right diaphragm and a probable small right pleural effusion. The patient's condition gradually deteriorated. In view of the failure to respond to treatment a diagnosis of neoplasm was 


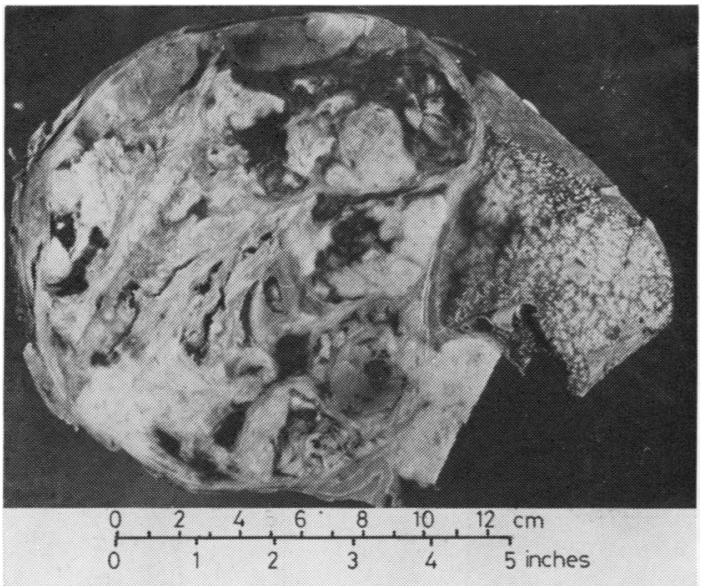

Fig. 1 Large uninodular tumour showing areas of haemorrhage and necrosis well demarcated from the adjacent congested liver.

seriously considered. At laparotomy there was a massive primary liver tumour, from which a wedge biopsy was taken. The patient died the same day.

\section{POSTMORTEM FINDINGS}

The liver was markedly enlarged (weight $4510 \mathrm{~g}$ ). There was a huge, uninodular tumour (Fig. 1), approximately $25 \mathrm{~cm}$ in diameter, arising in the superior aspect of the right lobe and extending upwards, pushing the diaphragm high into the thoracic cavity. It appeared well demarcated, by a pseudocapsule, from the remaining liver, which was congested but showed no evidence of cirrhosis.
There were extensive areas of calcification and necrosis. The elevation of the diaphragm resulted in compression of the pericardium, causing death by cardiac tamponade. The right lung contained many subpleural, soft white secondary deposits, up to $2 \mathrm{~cm}$ in diameter. There were no metastases to the peritoneum, and all the other organs appeared normal for age.

\section{Histology of liver tumour}

The tumour has a variegated appearance with a predominance of mesenchymal elements, which vary from primitive to mature, mixed with primitive and poorly or well differentiated epithelial cells. The cells of the epithelial tissue vary in size and have dark, densely hyperchromatic polygonal, round, or oval nuclei and abundant cytoplasm arranged as cords or trabeculae separated by thin fibrous septa indistinguishable from primary hepatocellular carcinoma (Fig. 2). Sometimes there is a poorly differentiated acinar appearance (Fig. 3); occasionally clefts separating groups of small and primitive cells resembling fetal liver can be seen. The acinar structures (Fig. 3) probably represent ductular differentiation. In the cellular areas, the mesenchymal elements take the form of spindle-shaped cells with elongated tapering nuclei, which show marked pleomorphism with multinucleate forms and increased mitotic activity. In some areas there are interlacing bundles of spindle cells reminiscent of fibrosarcoma (Fig. 4). No rhabdomyoblasts were found.

In many areas, however, particularly in the

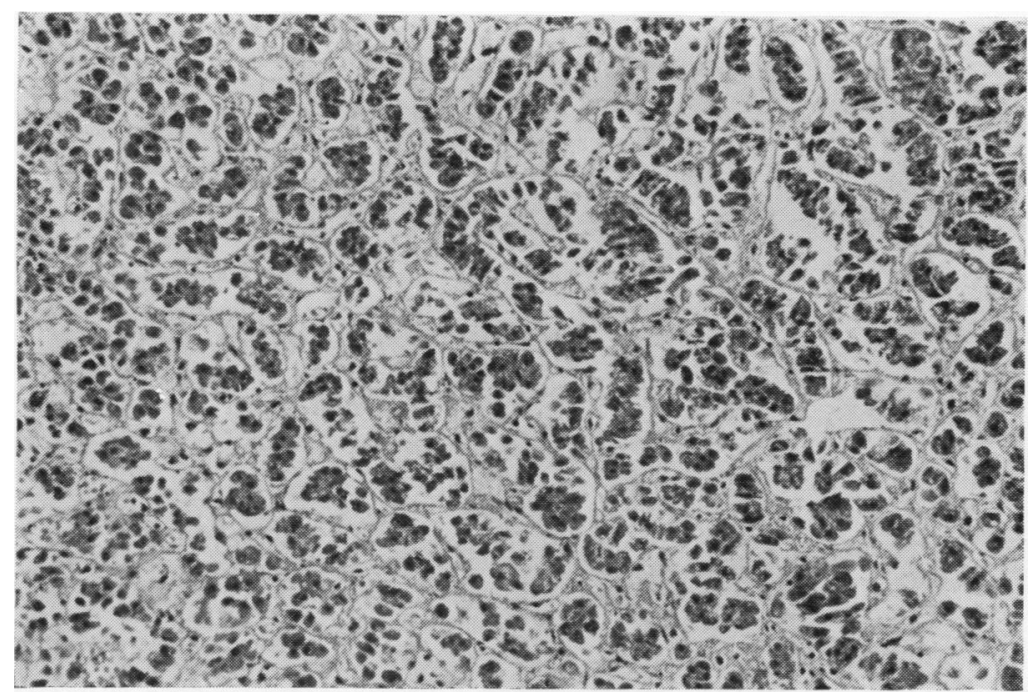

Fig. 2 Trabeculae of well differentiated epithelial cells separated by thin fibrous septa indistinguishable from hepatocellular carcinoma. Haematoxylin and eosin $\times 125$. 


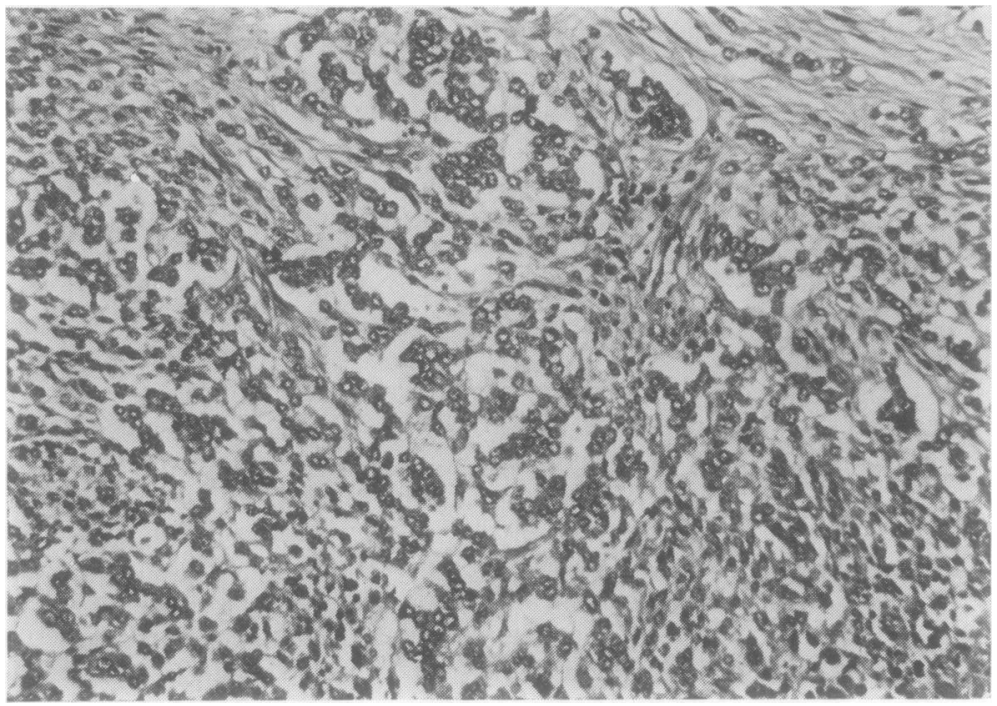

Fig. 3 Poorly differentiated acinar appearance. $H$ and $E$ $\times 125$. calcified region, the morphology is different, with poorly cellular, hyalinised fibrous tissue showing widespread calcification with prominent osseous differentiation (Fig. 5). Nowhere was there evidence of osteosarcoma, nor was any cartilage found. Sections from the pulmonary metastases show poorly differentiated epithelial cells, again showing cleft formation between adjacent cell groups and occasional acini, together with malignant mesenchymal tissue.

To summarise the histology, the malignant mesenchymal elements show areas resembling fibrosarcoma, spindle-shaped cells with tapering nuclei, marked pleomorphism, and multinucleated cells. In addition, there is dense fibrous tissue and bone. The epithelial elements show well differentiated hepatocellular carcinoma-like areas, poorly differentiated acinar appearance, or sheets of undifferentiated cells. The combination of mesenchymal and epithelial elements enable the diagnosis of mixed hepatoblastoma to be made.

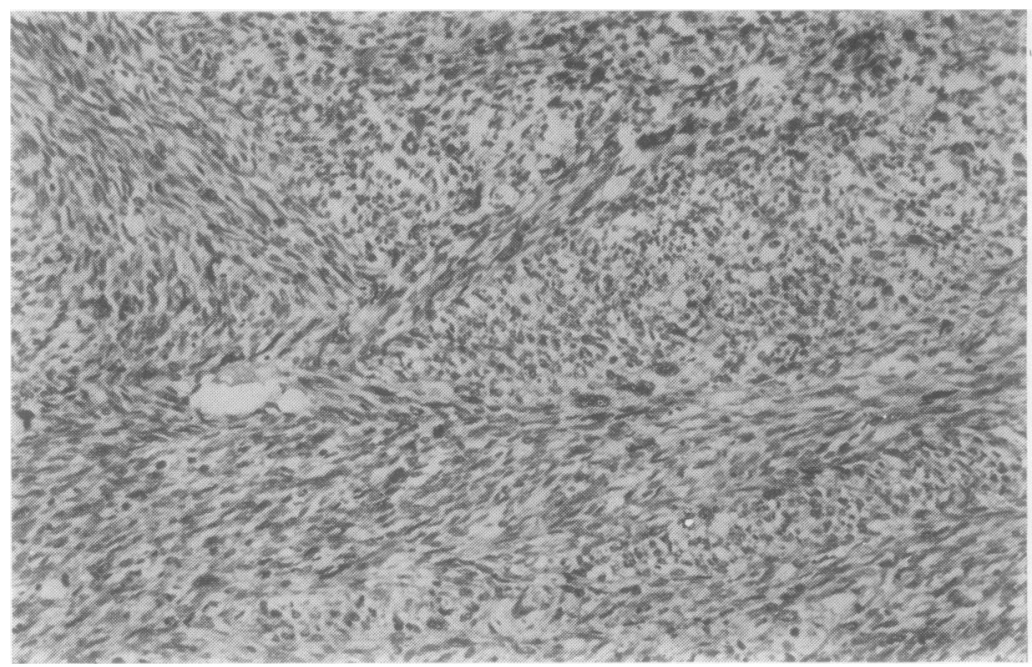

Fig. 4 Malignant mesenchymal tissue showing pleomorphic spindle-shaped cells and fibrosarcoma-like areas. $H$ and $E \times 125$. 


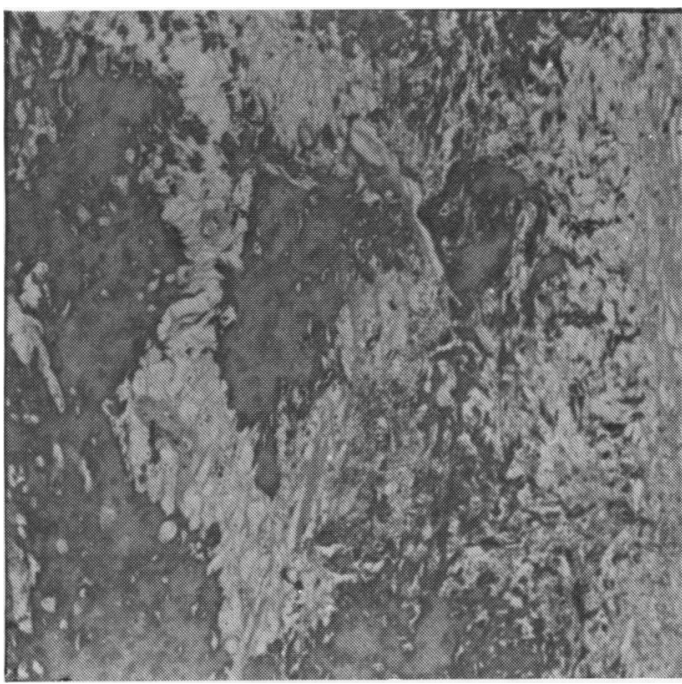

Fig. 5 Prominent osseous differentiation surrounded by dense fibrous tissue. $H$ and $E \times 150$.

\section{Literature review, histological features, and histogenesis of adult mixed hepatoblastoma}

Willis ${ }^{8}$ has divided hepatoblastoma into embryonic hepatoma and classical mixed hepatoblastoma. Embryonic hepatoma contains only neoplastic epithelial elements, and cases have not been recorded in adults. The diagnosis of mixed hepatoblastoma depends on the demonstration of both malignant mesenchymal and malignant epithelial elements. The latter include areas resembling embryonic liver; in these, cords and clusters of cells separated by sinusoid-like clefts may be seen together with glandular spaces lined by cuboidal epithelium, which represent bile ductule differentiation. Squamous metaplasia of this epithelium may occur. ${ }^{39}$ Areas of adenocarcinoma ${ }^{10}$ and hepatocellular carcinoma 461011 may be seen. Mesenchymal elements include myxoid connective tissue resembling primitive mesenchyme and areas resembling adult fibrosarcoma. ${ }^{10}$ Chondrosarcoma, ${ }^{410}$ osteosarcoma, and rhabdomyoblasts 71012 may be found. Fat, smooth muscle and neural elements are very unusual and, if found, an alternative diagnosis should be considered. In different tumours there are variable proportions of epithelial and mesenchymal elements. In some areas, primitive epithelial cells may show a characteristic intermingling with primitive myxoid connective tissue ${ }^{212}$ (and the present case), both these elements appearing to arise from a background mass of completely undifferentiated cells.

The Table covers all the cases in the English literature where the criteria for a diagnosis of adult mixed hepatoblastoma appear to have been fulfilled. The first two cases are from Milman's review of 'mixed tumours' of the liver. ${ }^{5}$ Descriptions are brief, and illustrations were not available, but it seems clear that mesenchymal and epithelial tissues were shown in a malignant uninodular tumour, both cases being without extrahepatic metastases. Many other cases of 'mixed tumour' were reviewed by Milman, but details are scanty and in general point to some other alternative diagnosis such as malignant teratoma or carcinosarcoma. Cases 3, 4, and 6-12 are clearcut, being fully described and illustrated. Cases 2 and 6 show the tumour occurring in cirrhosis. Here the diagnosis must be made with care to exclude carcinosarcoma. Case 8 is unusual in that the malignant tissues were all adult in type; primitive embryonic elements were not seen. However, the very diversity of elements present makes it difficult to postulate any other histological origin than the primitive hepatic blastema, or 'rest' cells derived therefrom.

Areas of dense, mature, poorly cellular, fibrous tissue showing necrosis and dystrophic calcification were prominent in Ludwig's cases and in our tumour. Osteoid may also be seen. ${ }^{313}$ Extensive calcification and ossification may be seen in some cases of hepatocellular carcinoma, ${ }^{14}$ and in such cases a careful search of the available material for mesenchymal elements should be made to exclude a possible alternative diagnosis of mixed hepatoblastoma. Tumours of both types showing this feature tend to be slow-growing with a long course between clinical onset and death. Hypertrophic osteoarthropathy occurred in one of Ludwig's cases.

Case 5 is difficult to assess as epithelial tissues were found only in metastases in hilar lymph nodes, but a coincident lung carcinoma was carefully excluded. Case 13 illustrates a potential problem in the differential diagnosis. Epithelial elements were only scanty and were found mainly in the periphery of the tumour. This raises the possibility that the tumour was an undifferentiated (embryonal) sarcoma, the glandular structures seen representing 'trapped' bile ducts, which may survive and sometimes even show hyperplasia in primary or metastatic liver sarcomas. ${ }^{15}$ However, in some parts of this tumour, squamous metaplasia of the gland epithelium was seen.

The modern theory of hepatic embryogenesis ${ }^{8}$ postulates a plastic primitive hepatic blastema, the cells of which may evolve directly to give rise to both mesenchymal and epithelial elements. An origin from such a cell makes the diverse histological features of mixed hepatoblastoma readily understandable. To explain the occurrence of the tumour 
Summary of 13 review cases

\begin{tabular}{|c|c|c|c|c|c|c|}
\hline Case & Ref. No. & $\begin{array}{l}\text { Sex/ } \\
\text { Age }(y r)\end{array}$ & $\begin{array}{l}\text { History at time } \\
\text { of diagnosis }\end{array}$ & Survival & Necropsy findings & Histology \\
\hline 1 & 5 (Citing Marx, 1904) & $\begin{array}{l}M \\
52\end{array}$ & 2 months & Died & $\begin{array}{l}\text { Uninodular tumour. } \\
\text { No metastases }\end{array}$ & $\begin{array}{l}\text { E: Epithelial tissue. } \\
\text { M: Blood vessels, syncytial } \\
\text { cells. } \\
\text { Author's diagnosis: mixed } \\
\text { tumour }\end{array}$ \\
\hline 2 & 5 (Citing Saltykow, 1914) & $\begin{array}{l}M \\
57\end{array}$ & $?$ & Died & $\begin{array}{l}\text { Cirrhotic liver. } \\
\text { Uninodular mass } \\
\text { right lobe. No } \\
\text { metastases }\end{array}$ & $\begin{array}{l}\text { E: Liver parenchyma, } \\
\text { alveolar structure. } \\
\text { M: Myxoid tissue, bone, and } \\
\text { cartilage. } \\
\text { Author's diagnosis: carcino- } \\
\text { osteochondromyxosarcoma }\end{array}$ \\
\hline 3 & 12 & $\begin{array}{l}M \\
35\end{array}$ & 3 months & $\begin{array}{l}\text { Died one month } \\
\text { after surgery }\end{array}$ & $\begin{array}{l}\text { Liver } 8500 \text { g. Massive } \\
\text { tumour replacing } \\
\text { most of organ. No } \\
\text { distant spread }\end{array}$ & $\begin{array}{l}\text { E: Fetal liver. } \mathbf{M} \text { : Primitive } \\
\text { connective tissue stroma, } \\
\text { spindle cell area with } \\
\text { prominent rhabdomyoblasts. } \\
\text { Author's diagnosis: embryonic } \\
\text { tumour of liver }\end{array}$ \\
\hline 4 & 2 & $\begin{array}{l}F \\
68\end{array}$ & $\begin{array}{l}3 \text { months (post- } \\
\text { mortem diagnosis) }\end{array}$ & Died & $\begin{array}{l}\text { Uninodular mass } \\
\text { right lobe }(15 \mathrm{~cm} \\
\text { diam }) \text {. No } \\
\text { metastases }\end{array}$ & $\begin{array}{l}\text { E: (predominant) Fetal liver, } \\
\text { acinar and tubular structures. } \\
\text { M: (scantier) Myxoid tissue } \\
\text { and cartilage. } \\
\text { Author's diagnosis: primary } \\
\text { mixed tumour }\end{array}$ \\
\hline 5 & 13 & $\begin{array}{l}M \\
48\end{array}$ & $\begin{array}{l}3 \text { months (post- } \\
\text { mortem diagnosis) }\end{array}$ & Died & $\begin{array}{l}\text { Liver } 3800 \mathrm{~g} \text {. Large } \\
\text { tumour right lobe. } \\
\text { Metastases para- } \\
\text { tracheal and hilar } \\
\text { lymph nodes }\end{array}$ & $\begin{array}{l}\text { E: Hepatocellular carcinoma } \\
\text { in lymph nodes. M: 'Round' } \\
\text { and 'spindle cell' sarcoma, } \\
\text { chondrosarcoma, and osteoid. } \\
\text { Author's diagnosis: } \\
\text { ?malignant mixed tumour }\end{array}$ \\
\hline 6 & 6 & $\begin{array}{l}M \\
56\end{array}$ & $\begin{array}{l}1 \text { month (known } \\
\text { hepatosplenomeg- } \\
\text { aly many years) }\end{array}$ & $\begin{array}{l}\text { Sudden death } \\
\text { intraperitoneal } \\
\text { haemorrhage }\end{array}$ & $\begin{array}{l}\text { Micronodular } \\
\text { cirrhosis. Large } \\
\text { uninodular mass } \\
\text { right lobe. } \\
\text { No metastases }\end{array}$ & $\begin{array}{l}\text { E: Fetal liver, glandular } \\
\text { structures, adult hepato- } \\
\text { cellular carcinoma. } \\
\text { M: Myxoid connective tissue, } \\
\text { osteoid; no bone, cartilage } \\
\text { or muscle. } \\
\text { Author's diagnosis: hepatic } \\
\text { embryonic mixed tumour }\end{array}$ \\
\hline 7 & 3 & $\begin{array}{l}M \\
84\end{array}$ & 4 months & $\begin{array}{l}\text { Died after } \\
\text { surgery }\end{array}$ & $\begin{array}{l}\text { Liver } 3000 \mathrm{~g} . \text { Tumour } \\
\text { multinodular } \\
\text { (mainly right lobe). } \\
\text { No metastases }\end{array}$ & $\begin{array}{l}\text { E: Fetal liver, glandular and } \\
\text { tubular structures, occasional } \\
\text { islands of squamous } \\
\text { epithelium. } \\
\text { M: Myxoid connective tissue, } \\
\text { chondral and osteoid foci. } \\
\text { Author's diagnosis: mixed } \\
\text { malignant tumour }\end{array}$ \\
\hline 8 & 10 & $\begin{array}{l}M \\
78\end{array}$ & 1 month & $\begin{array}{l}\text { Sudden death } \\
1 \text { month after } \\
\text { surgery }\end{array}$ & $\begin{array}{l}\text { Liver } 2200 \mathrm{~g} \text {. Uni- } \\
\text { nodular mass } \\
19 \times 13 \times 6 \mathrm{~cm} \text { left } \\
\text { lobe containing } \\
\text { bone. No metastases. } \\
\text { Pulmonary emboli }\end{array}$ & $\begin{array}{l}\text { E: Glandular structure, } \\
\text { adenocarcinoma, adult } \\
\text { hepatocellular carcinoma. } \\
\text { M: Fibrosarcoma, osteo- } \\
\text { sarcoma, chondrosarcoma, } \\
\text { occasional rhabdomyoblasts. } \\
\text { Author's diagnosis: } \\
\text { hepatoblastoma }\end{array}$ \\
\hline 9 & 7 & $\begin{array}{l}F \\
65\end{array}$ & 4 months & Sudden death & $\begin{array}{l}\text { Liver } 3500 \mathrm{~g} \text {. } \\
\text { Uninodular tumour } \\
\text { right lobe } 25 \times 15 \times \\
10 \mathrm{~cm} \text {. No metastases }\end{array}$ & $\begin{array}{l}\text { E: Fetal liver and adult } \\
\text { hepatocellular carcinoma. } \\
\text { M: Embryonal rhabdo- } \\
\text { myosarcoma. } \\
\text { Author's diagnosis: } \\
\text { rhabdomyosarcohepatoma }\end{array}$ \\
\hline 10 & 11 & $\begin{array}{l}F \\
19\end{array}$ & 2 months & $\begin{array}{l}\text { Right hepatic } \\
\text { lobectomy. } \\
\text { Follow-up not } \\
\text { known }\end{array}$ & $\begin{array}{l}\text { Uninodular mass } \\
19 \mathrm{~cm} \text { diam, weight } \\
1900 \mathrm{~g}\end{array}$ & $\begin{array}{l}\text { E: Fetal liver, adult } \\
\text { hepatocellular carcinoma. } \\
\text { M: Primitive connective } \\
\text { tissue; scanty osteoid. } \\
\text { Author's diagnosis: } \\
\text { hepatoblastoma }\end{array}$ \\
\hline 11 & $4($ case 1$)$ & $\begin{array}{l}F \\
53\end{array}$ & $\begin{array}{l}5 \text { years known } \\
\text { hepatomegaly }\end{array}$ & $\begin{array}{l}\text { Died after } \\
\text { surgery }\end{array}$ & $\begin{array}{l}\text { Liver } 2515 \text { g. Multi- } \\
\text { nodular tumour } \\
\text { (mainly right lobe). } \\
\text { Prominent calcifi- } \\
\text { cation. Metastases } \\
\text { spleen, peritoneum, } \\
\text { marrow }\end{array}$ & $\begin{array}{l}\text { E: (scanty) Fetal liver, adult } \\
\text { hepatocellular carcinoma. } \\
\text { M: (predominant) Myxoid } \\
\text { connective tissue, acellular } \\
\text { fibrous tissue, foci of necrosis } \\
\text { and calcification. } \\
\text { Author's diagnosis: mixed } \\
\text { malignant tumour }\end{array}$ \\
\hline
\end{tabular}




\begin{tabular}{|c|c|c|c|c|c|c|}
\hline Case & $\operatorname{Ref.}$ No. & $\begin{array}{l}\text { Sex/ } \\
\text { Age }(y r)\end{array}$ & $\begin{array}{l}\text { History at time } \\
\text { of diagnosis }\end{array}$ & Survival & Necropsy findings & Histology \\
\hline 12 & 4 (case 2$)$ & $\begin{array}{l}M \\
40\end{array}$ & $\begin{array}{l}\text { Hepatic calcifi- } \\
\text { cation } 18 \text { months }\end{array}$ & $\begin{array}{l}\text { Died } 9 \text { months } \\
\text { after diagnosis }\end{array}$ & $\begin{array}{l}\text { Liver } 4500 \text { g. } \\
\text { Described as large } \\
\text { uninodular mass } \\
\text { right lobe with } \\
\text { intrahepatic } \\
\text { metastases. } \\
\text { Marked calcification. } \\
\text { Metastases lymph } \\
\text { nodes and lung }\end{array}$ & $\begin{array}{l}\text { E: Fetal liver. } \\
\text { M: Similar to those in } \\
\text { Ludwig's case } 1 \text {. } \\
\text { Author's diagnosis: mixed } \\
\text { malignant tumour }\end{array}$ \\
\hline 13 & 9 & $\begin{array}{l}F \\
51\end{array}$ & 1 year & $\begin{array}{l}\text { Died before } \\
\text { surgery }\end{array}$ & $\begin{array}{l}\text { Tumour right lobe } \\
12 \times 10 \times 10 \mathrm{~cm} \\
\text { Metastases } \\
\text { abdominal lymph } \\
\text { nodes and pleura }\end{array}$ & $\begin{array}{l}\text { E: (scanty) Glandular } \\
\text { structures, squamous } \\
\text { metaplasia. } \\
\text { M: (predominant) Spindle } \\
\text { cell sarcoma, no cartilage or } \\
\text { bone. } \\
\text { Author's diagnosis: } \\
\text { hepatoblastoma }\end{array}$ \\
\hline
\end{tabular}

$E=$ epithelial $; m=$ mesenchymal.

in adults, one has to suggest primitive 'rest cell' persistence 5 or possibly dedifferentiation of liver cells, which are then capable of showing a plastic redifferentiation in response to the neoplastic stimulus. ${ }^{6}$

\section{Conclusion}

Mixed hepatoblastoma in adults is extremely rare and affects mainly the middle-aged and elderly, most of the cases occurring after the age of 45 . In two of the 13 cases reviewed, cirrhosis was present. The terminology is confused, and several names have been used to describe this tumour. A review of the histology of cases described as mixed malignant tumour, or similar names, shows that many, but not all, of these are examples of adult mixed hepatoblastoma. True hepatic teratomas and carcinosarcomas, for example, will have to be excluded before the diagnosis can be made. The ambivalent term 'mixed malignant tumour' does not constitute a definitive diagnosis and could therefore be dropped.

\section{References}

${ }^{1}$ Kasai M, Watanabe I. Histological classification of liver cell carcinoma in infancy and childhood, and its clinical evaluation. Cancer 1970;25:551-63.

2 Alexander M. A mixed tumour of the liver in an adult. $J$ Pathol $1961 ; 82: 217-9$.
${ }^{3}$ Blanding J. Mixed malignant tumours of liver in adults. Case report and review of some features. Arch Pathol Lab Med 1968;86:108-10.

${ }^{4}$ Ludwig J, Grier M, Hoffman H, McGill D. Calcified mixed malignant tumour of the liver. Arch Pathol Lab Med 1975;99:162-6.

${ }^{5}$ Milman D, Grayzel D. Mixed tumour of the liver. Report of a case with review of the literature. Am J Dis Child $1951 ; 81: 408-20$.

- Kerr JF. Hepatic embryonic mixed tumour in an adult. $J$ Pathol 1966;92:238-40.

7 Goldman R, Friedman N. Rhabdomyosarcohepatoma in an adult and embryonal hepatoma in a child. Am J Clin Pathol 1969;51:137-43.

${ }^{8}$ Willis RA. Pathology of Tumours. 3rd ed. London: Butterworth, 1960;934-8.

- Jameson CP. Hepatoblastoma in a middle aged South African woman. SA Med J 1978;53:143-4.

${ }^{10}$ Carter R. Hepatoblastoma in the adult. Cancer $1969 ; 23$ : 191-7.

${ }^{11}$ Meyer P, Livolsi V, Cornog J. Hepatoblastoma associated with oral contraceptive. Lancet 1974;2:1387.

12 Barnett W, Erikson E, Halpert B. Embryonic tumour of the liver in an adult. Cancer $1958 ; 11: 306-9$.

13 Ojima MA, Sugiyama T, Takeda T et al. Six cases of rare malignant tumours of the liver. Acta Pathol Jpn 1964; 14:95-102.

${ }^{14}$ Morgan A, Walker W, Mason M, Herlinger H, Losowsky M. A new syndrome associated with hepatocellular carcinoma. Gastroenterology 1972;63:340-5.

${ }^{15}$ Stocker T, Ishak K. Undifferentiated embryonal sarcoma of the liver: report of 31 cases. Cancer 1978;42:336-48.

Requests for reprints to: Dr MT Haqqani, Walton Hospital, Rice Lane, Liverpool, UK. 